\title{
Balances of Current Political Transition in Azerbaijan, Dynamics and Expectations
}

\author{
Sabir Mirzazada* \\ Sapienza University Roma, Political Sciences-International Cooperationa and Development, Italy \\ *Corresponding Author: Sabir Mirzazada, Sapienza University Roma, Political Sciences-International \\ Cooperationa and Development, Italy
}

\begin{abstract}
After collapse of Soviet Union, many countries could achieve their political transitions to democracy from past system, The fact is post-soviet countries have different democratic transition process since the collapse of the Soviet Union. All these countries have some challenges about adaptation to new system and for create consolidation of democracy. If we express briefly: economic, political and structure of community had to change in these countries for transition, because the Soviet Union was not the only country that was managed by strong dictatorship also it had own system and their communities were built for this system over decades. Some countries emerged after The Soviet period They were Modern, independent but were ruled by the authoritarian regimes, Their dresses, shoes and all lifestyles were similar to Europe, only government style except. In this paper, we are going to try to analyse transition and democratisation challenges for one of these authoritarian regimes-Azerbaijan, even after the color revolutions of the postcommunist region, it can be classified as the last powerful castle of Authoriharianism in East Europe and Sothern Caucasuswhich empowers the future generation and it should always be the main concern of any nation.
\end{abstract}

Keywords: Democratic Transition, Southern Caucasus, Authoritarian Regimes, The Post-Soviet region, Controlled Transition

\section{INTRODUCTION}

Only Baltic countries could actualized that process quickly more than other "brothers". It is amazing point that "winds of democracy" was coming from West to East, we must say its speed was very low . After all processes, Ukraine, Georgia and Armenia, two main countries have resistance for this change in near of Europe: Belaus , Azerbaijan. Belarus is "last castle of Russian Empire" against democracy and liberalization flows. On the other hand, Azerbaijan was characterized as "democracy key" for Central Asia, so If Azerbaijan achieve that, region destiny would be different from current situation for transition speed. Azerbaijan have different and special relationships with different powers, Although Mr Aliyev can be caracterised as ally of Putin and one member of his(Putin) leaders club, These scene do not interfere good communications with West. Although the European Union occasionally expresses "political inconvenience" for certain freedoms (the EU parliament's latest resolution to arrest journalist Mehman Huseynov) ${ }^{\mathbf{1}}$, it does not generally impose any sanctions or restrictions to Aliyev family and his cabinet for their policy. Political oppositions are very weak for any influential effect for the regime but the weakness of oppositions don't mean as the popularity of the current regime, The fact is something must change in regime and Never they would not desire these transitions, which realize by masses of people, so Regime, looking for formulas of "Controlled transition"

\section{SECULARISM AGAINST TO RELIGIOUS OPPOSITIONS - ADVANTAGE OF REGIME}

Many pages were written about analyses of geographical importance of Azerbaijan, So its position in the north of Iran, as the bridge to Central Asia and Afghanistan, are very important for USA and NATO forces, also it is an indispensable boon for Israel, it is meaning that political circles of TelAviv never agree to any non-secular government for Baku. The 5-day visit by the Israeli Defense Minister (Avigdor Liberman) at the time in September last year also confirmed the importance of these relations for Israel ${ }^{2}$. So Aliyev family is one of main samples with their secular lifestyle in the Muslim region after the Pahlavi dynasty. This character of the current administration is the positive 
side for Western countries. Even it is possible to argue that secularism is the most valuable "tool" for answers to "demands of democracy" from Europe and the USA. Under the same propaganda, the regime is very rigid to his religious opposites, that they have accepted Vilayat e Faghih as holy leadership .It is meaning that, İranian Supreme Leader is common to head of All Muslims and he has proxy Islam Prophet. In this case, the Azerbaijan administration is doing powerful operations against them in the country ${ }^{3}$, So it resulted in the weakening of one of his opposition forces also regime shows these operations as a "struggle of secularism " to Western Block and Israel.

\subsection{Influence of Secular Political Oppositions to Political Processes}

After a year's administration period (1992-1993), political oppositions of the country had entered their condescension time and every year and every election they have lost their play area and reputation. Their challenges for the adaptation process to the new community, also powerful pressures from the regime were effective for these processes. They have not any member in parliament and the main block of these forces had not participated in the last election for parliament, also presidential election was boycotted by them for sudden date changing in the election. After 2016 September, by general referendum, official powers of the president have increased by new supplements in the current constitution and vice-president chair was created and Mr. Aliyev appointed one member of his family for that new position, Mrs. Aliyeva ${ }^{4}$ On the other hand, Mr. Aliyev got authority for the dissolving of parliament with this constitution. ${ }^{5}$. Many political experts criticized useless activity of political opposition in these changes and they claim that these processes were taking the country to the back and Azerbaijan have lost its democratic gains, which were got by independence in the 90s. And what are the reactions of oppositional forces to it?!

\subsection{Two Types of Secular Political Oppositions: Bolsheviks and the Kadets}

Although all unavailable conditions of free political ambiance, during the 26 year Aliyevs period, political opposition of country could protect their existence, sometimes powerful, sometimes very weak but every time they were the political arena. So today they are represented by two main political actors in the stage as secular oppositional forces, Azerbaijan Popular Front Party (APFP) and Republican Alternative Party (REAL). That is interesting point, recent months their struggle headed to each other more than Aliyev's administration. Now we try to describe their current position more than their historical past or official declarations. That is fact, The Freedom House ${ }^{6}$ and Human Rights Watch reports ${ }^{7}$ were not bright about freedoms and liberties in the country, also OSCE reports ${ }^{8}$ about last election. İ this case political powers, even ruling elite and community are agreed in "somethings must change". But main problem is the method. Also, this method approach divided oppositions. The situation is a similar little bit to the beginning of the last century, Russia, Romanovs, and their oppositions APFP has a palpable organizational structure in the capital city and regions. The main reason for that structure is age and experience of party on the other hand features of their members are suitable for hard political struggles or political meetings. İn the last unauthorized demonstration in the center of the country's capital, the similar signs were clearly seen by the internal and foreign public'. The only and true power of a crowded People's Front, They were not many, but not afraid of the police forces who similar to armies of the Middle Ages, is the most important reason for the current administration to put more pressure on this party than the other groups. However, they are not the general view of the Azerbaijan population but they are people who have experience and capacity for any political campaign and these properties are very similar to the bolsheviks of the Russian Revolution. Many political actors claim that the party has not democracy and competitiveness in internal structure and only real law for movement is chairman"s "view" who had this title since 2000. Thus it may accept as normal, after long -time and heavy struggle against very powerful regime, also party has sacrificed many activists as political prisoners during that period. Their political program for the future is not very transparent but their aim is more evident:"Overthrow The Aliyev" .But this aim is not as next pillar of democratic transition for them, it is more like the final victory in the long-term painful war. On the other hand, the REAL has a different way for the transition of democracy. They often criticize the method of APFP (for example as their political meetings attempts or boycott of the election). REAL chairman I.Mamedov always emphasizes the importance of election for the democratization process, whereas APFP describes elections as "Decoration of Legitimacy" for the regime. That is fact REAL is a new party and they have not sufficient capacity for wide political meetings as Popular Front. In this way REAL advocates, internal reforms and oppositional struggle by parliament more than other paths and they criticize the APFP mentality of change harshly. According 
to them, the Democratic transition must not present as a "revolutionary war". So their approaches are a little bit similar to the Kadets of the Russian Revolution period. In the words of famous Kadet Pavel Miliukov:" The opposition of His Majesty, not opposition to His Majesty". REAL with similar approaches, unofficially emphasize something for the regime:" We are not "bolsheviks" and we can work together in democratic reforms".

\section{EXPECTATIONS FOR TRANSITIONS AND DYNAMICS}

We have characterized secular oppositions of regime similarities with oppositions od Romanovs but that is fact, Aliyev administration situation has some differences from the Revolutionary time administration of the Russian Empire. Romanov Dynasty has faced Huge War, tragedic conditions of the economic situation of masses, the current administration has similar discomforts but they are not absolutely the same level of danger as The Romanovs. These conditions also other difficulties decrease the influence of political oppositions to regime and people. Semi -frozen local war with Armenia, balanced foreign relationships, semi-sustainable economical conditions for middle classes and missing activity of oppositions provide to the regime, continuing the same path for management. However, all these sustainable conditions for regime, some disagreements among ruling elites components may obligate regime for changing something. As emphasized at introduction, insufficient popularity and weak influence of secular oppositions do not mean as more popularity of the current government in people. Although all economic and political resctrictions, current oppositional forces save their chance yet for any semi-free elections. Mr president Aliyev is the most powerful person in country and political scene but he is not the most popular person for community. Mr.Aliyev aims to increase the rating for the wider masses by liquidating the remaining cadres from the previous president (Father Aliyev) and strengthening his hand. While the political and economic power is gathered in a narrower environment, the Aliyev family and the surrounding area, the Polit bureau during Heydar Aliyev loses power. Former President Aliyev established his administration mainly through Azerbaijanis of Nakhchivan and Armenian descent, and these two groups formed strong support among people. There is no strong resistance to this change, but it seems that there is no group among the public on which the new structure is based. So The Aliyevs will need mass rating in this new era. Thus the fact is the most popular figure or the second powerful person of ruling elite Mrs. Aliyeva may be a key factor of the new period. With long-standing parliamentary membership and the country's largest charity organization (Heydar Aliyev Foundation), She represents the soft power of the regime. On the other hand she has well-known family in internal community, His grandfather Jalal Pashayev was famous author in Soviet Azerbaijan, her uncle Hafiz Pashayev worked as ambassador of Azerbaijan in USA. They have good relations with Western and Russian circles as a family. She has also important relations with institutions such as UNESCO and İSESCO, is well known in European circles for her cultural investments and projects ${ }^{\mathbf{1 0}}$.

\section{CONCLUSION}

After The Color Revolutions and regime changes of Georgia and latest Armenia, Azerbaijan was characterized as the last castle for authoritarianism in the Caucasus, Besides some change trends for the political scene of the country. But the point is, can these changing attempts convert any democratic transition? Current situation of secular oppositions cannot seem available for any transition through democracy. It is clear that the possible and first steps of change are more related to the balance of power of ruling elites than any democratic transition. On the other hand if oppositions can achieve to attract people to the political scene again, everything can be different in the next moths. In this case, transition of power will not easy for The Aliyev family. However, In the period when all its neighbors in the Caucasus are taking important steps for parliamentary democracy, the fact that the political circles in Baku to hope something from the inner dynamics of a regime does not promise good prospects for democracy. Finally, If Democratic forces of the country cannot interfere and continue to stay as "fan" in these transition of power, it may be their the worst also the last defeat

\section{REFERENCES}

[1] http://www.europarl.europa.eu/doceo/document/RC-8-2019-0056_EN.html on Azerbaijan, notably the case of Mehman Huseynov (2019/2511(RSP))-16.01.2019

[2] https://www.jpost.com/Israel-News/Liberman-visits-Azerbaijan-to-strengthen-ties-with-countrybordering-Iran-567152 Liberman visits Azerbaijan 
[3] https://www.rferl.org/a/azerbaijan-nardaran-raid/27400436.html Nardaran operation

[4] https://www.washingtonpost.com/news/worldviews/wp/2017/02/22/azerbaijans-president-has-chosen-anew-vp-his-wife/ Mehriban Alieva ,Vice-presidency

[5] https://www.rferl.org/a/azerbaijan-referendums-constitutional-changes-aliyev/28012681.html

[6] https://freedomhouse.org/report/freedom-world/2019/azerbaijan Report for Azerbaijan Freedom House

[7] https://www.hrw.org/world-report/2019/country-chapters/azerbaijan Report for Azerbaijan Human Rights Watch

[8] https://www.osce.org/odihr/elections/azerbaijan Reports of Elections OSCE

[9] https://www.independent.co.uk/news/world/azerbaijan-police-detain-protesters-ali-kerimli-popular-fronta9163006.html

[10] http://www.cultura.va/content/cultura/en/collegamenti/archeologia-sacra/mar.html

Citation: Sabir Mirzazada. "Balances of Current Political Transition in Azerbaijan, Dynamics and Expectations" International Journal of Political Science (IJPS), vol 5, no.4, 2019, pp. 55-58. doi: http://dx.doi.org/10.20431/ 2454-9452.0504009.

Copyright: (C) 2019 Authors. This is an open-access article distributed under the terms of the Creative Commons Attribution License, which permits unrestricted use, distribution, and reproduction in any medium, provided the original author and source are credited. 